\title{
A democracia sequestrada: mídia e poder no Brasil atual
}

Luiz Alberto Grijó*

Resumo: $\mathrm{O}$ artigo busca analisar como se comportaram os meios de comunicação social no Brasil desde a ditadura civil-militar até os dias de hoje. Atrelados às grandes empresas do setor, o que é atualmente melhor designado por grande mídia, os meios passaram a exercer no mundo social como um todo, em especial em relação às novas condiçôes do fazer política que se abriam com o processo da chamada abertura democrática, uma posição central na sociedade e, especialmente, quanto às disputas políticas. De rebocados pela política, passaram a reboca-la, postando-se como guardiães e intérpretes da democracia, emprestando-lhe o sentido que melhor lhes convém.

Palavras-chave: Meios de Comunicação. Golpe de estado e mídia. Democracia e mídia.

\section{Introdução}

No final da década de 1970 e início da de 1980, com a crise e iminente dissoluçáo do regime civil-militar implantado desde 1964 no Brasil, abriu-se um leque de possibilidades aos agentes sociais e políticos. Algo novo traçava-se, ao mesmo tempo em que antigas organizaçóes tentavam se reestruturar. O Partido dos Trabalhadores (PT) e o chamado novo sindicalismo, o fim da censura oficial, a tentativa de Leonel Brizola e de outros antigos militantes de refundar o Partido Trabalhista Brasileiro (PTB), o retorno ao país dos exilados,

\footnotetext{
* Professor-Associado do Departamento de História e do PPG em História da Universidade Federal do Rio Grande do Sul - UFRGS. Doutor em História pela Universidade Federal Fluminense - UFF. E-mail: lgrijo@uol.com.br.
}

Anos 90, Porto Alegre, v. 23, n. 43, p. 67-92, jul. 2016 
da autonomia das organizaçôes estudantis e da competição eleitoral como forma de seleção principal dos agentes políticos, as discussóes sobre a anistia. Não só na sociedade como um todo, mas também em determinados setores, as novas condiçôes implicaram adequação, adaptação, reestruturação. Se as oposiçôes ao regime ditatorial organizaram-se em novos partidos políticos, os seus apoiadores também o fizeram. Se a imprensa de vanguarda, um tanto marginal, mas ativa, teve papel importante no enfrentamento político ao regime que findava, a chamada grande imprensa foi mais ou menos a reboque do que ocorria no resto da sociedade, cumprindo também um papel significativo no processo como um todo.

Assim, dadas as novas condiçôes que estavam sendo criadas, ao mesmo tempo em que o regime anterior ía resistindo a elas e com elas transacionando, o que não impediu que se fosse esboroando e desestruturando, perdendo suas bases de sustentação, ao longo de um processo de mais ou menos dez anos, neste artigo busca-se analisar como se comportaram no período em linhas gerais os meios de comunicação atrelados às grandes empresas do setor, que papel a grande mídia passou a exercer no mundo social como um todo e em relação às novas condiçôes de fazer política que se abriam e, por fim, como este posicionamento foi se consolidando e desdobrando ao longo dos anos até o momento presente.

\section{O partido da mídia}

A crise geral que se intensificou nos anos de 2015 e 2016, especialmente como crise político-institucional, permite tomar o momento atual como uma espécie de balizador analítico para se estudar o que o antecedeu e de que modo a situação veio a ser tal qual é. As condiçóes do momento não são tomadas com o objetivo de reificar o presente como o fim de um processo, fim no duplo sentido de finalidade e de término, mas como um referencial privilegiado, um recurso metodológico, pois, como momento de crise profunda, inclusive de ruptura institucional, insta os participantes a tomarem posiçóes, encarnando-as em muitos casos, dentre os pontos de vista em acirrada disputa. Embora frequentemente traumáticas, duras, 
sofridas, temerárias e incertas para os envolvidos, crises agudas são muito importantes sob o ponto de vista analítico. Nelas os meiostermos dissipam-se, agentes descem dos muros e se posicionam abertamente, aqueles que se abrigam, ou escondem, sob mantos institucionais acabam revelando de que lado estão e a quais interesses ou senhores servem.

Em 2016, é clara a tomada de posição en bloc da grande mídia empresarial brasileira ao lado dos agentes do golpe de estado que se desenrola. No momento da escrita deste artigo, início de maio de 2016, ainda é presidenta da república Dilma Rousseff, mas na mídia já se anuncia e prenuncia o "novo governo" de Michel Temer, seu vice, que deverá assumir caso o processo de impeachment que corre no Senado a condene à perda do mandato. É quase unanimidade que o "governo do PT" acabou e que o "novo" já se apronta para assumir. Em um programa de rádio, pôde-se ouvir que o "time de Temer" já se encontra "fardado", aquecendo à beira do gramado, aguardando para "entrar em campo" (RÁDIO GAÚCHA, 2016). Independentemente do que venha a ocorrer, as posiçôes já estão tomadas, mais ou menos cristalizadas e em confronto. No caso da grande mídia, não só o apoio, mas seu protagonismo no desenrolar do golpe de estado foi ficando cada vez mais claro e explícito.

Em dezessete de abril, um domingo, a Câmara dos Deputados votou pela permissão da abertura do processo de impeachment da presidenta, passo decisivo no sentido do desfecho esperado pelos articuladores do golpe: o afastamento de Dilma Rousseff. A imprensa internacional, que já prestava alguma atenção ao que ocorria no Brasil, trouxe para as suas manchetes de capa a situação. Na semana que se iniciava, a rede CNN veiculou uma matéria a respeito. É questionado o motivo pelo qual a presidenta estaria sendo processada, qual teria sido o crime que cometera e que justificaria o afastamento cujo processo se abria com a votação do dia dezessete. É mostrada a acusação que embasa a denúncia, as chamadas pedaladas fiscais, mas é referido também que Dilma não é acusada pessoalmente de nenhum crime de corrupção ou qualquer outro. A âncora, Christiane Amanpour chama a participaçáo do repórter investigativo ganhador do prêmio Pulitzer, Glenn Greenwald, questionando-o sobre o que estaria no coraçáo deste drama político. 
Greenwald, que vive no Brasil com seu companheiro David Miranda, é reconhecidíssimo internacionalmente no meio jornalístico. Além do Pulitzer, ganhou no próprio Brasil o prêmio Esso de jornalismo, sendo o primeiro não brasileiro a recebê-lo (ver seu perfil no sítio de The Intercept, 2016). Em outras palavras, em se tratando do meio jornalístico-investigativo internacional, Greenwald é da primeiríssima linha em termos de reconhecimento e consagração inter-pares.

Para Greenwald, "[...] o tom dos procedimentos no Congresso foi extremamente duro, muito feio." Inclusive com "defensores do impeachment" manifestando-se em prol do golpe militar de 1964, apoiando a ditadura e, inclusive, "exaltando torturadores". Tais "procedimentos horríveis", que refletem uma "divisão perigosa do país", foram conduzidos pelo presidente da Câmara, Eduardo Cunha, sobre o qual pesam indícios fortíssimos de corrupção, com fortunas em contas na Suíça sem ter os meios lícitos de acumular tais recursos, "[...] a coisa mais surreal que vi em minha profissão de jornalista, que nunca vi em qualquer outro lugar do mundo cobrindo política". $\mathrm{O}$ processo seria conduzido pelos "[...] plutocratas brasileiros, os ricos, que sempre odiaram o PT [...]" e que, não conseguindo derrotá-lo nas urnas e se aproveitando da difícil situação econômica e do descrédito do governo e da "classe política, "[...] estão usando estes meios antidemocráticos para faze-lo", para "[...] se livrarem do PT". Por fim, o repórter salienta que a "preocupaçáo" é de que a "[...] intenção dos que querem o impeachment [...]" seja apenas alardear "[...] vejam, nos livramos da corrupçáo", enquanto que o que efetivamente esperam é que "a pressão da mídia" e a eventual "pressão pública" esvaneçam "junto com a catarse do impeachment". Enfim, os verdadeiros corruptos e corruptores apostam que "[...] as investigaçóes vão acabar [...]", para que voltem a estar "[...] protegidos" (CNN, 2016). ${ }^{1}$

No dia 21 de abril, o companheiro de Greenwald, David Miranda, publica um artigo no The Guardian. Miranda não é jornalista. Brasileiro de nascimento é um ativista político-social. Seu texto é mais direto e explícito, embora essencialmente convirja com as afirmaçóes e avaliaçôes de Greenwald veiculadas pela CNN. Miranda ressalta os dados-chaves do processo, de que o impeachment está sendo urdido pelas elites conservadoras, os "plutocratas", pelos verdadeiros corruptos, como uma forma de assumir o poder 
sem precisar de eleiçôes, como uma ação que lança mão de meios antidemocráticos para chegar ao poder. Mas o que mais interessa aqui é que Miranda dá nome a certos bois.

A história da crise política no Brasil, e a mudança rápida da perspectiva global em torno dela, começa pela sua mídia nacional. A imprensa e as emissoras de TV dominantes no país estão nas mãos de um pequeno grupo de famílias, entre as mais ricas do Brasil, e são claramente conservadoras. Por décadas, esses meios de comunicação têm sido usados em favor dos ricos brasileiros, assegurando que a grande desigualdade social (e a irregularidade política que a causa) permanecesse a mesma (MIRANDA, 2016, s.p.).

Miranda chama o que se passa de "golpe" e responsabiliza diretamente não só a plutocracia e os políticos, "[...] evangélicos extremistas, apoiadores da extrema direita que defendem a volta do regime militar, figuras dos bastidores sem ideologia alguma [...]", mas a também não menos plutocrática mídia. Boa parte dos grupos de mídia brasileiros "[...] - que aparentam ser respeitáveis para quem é de fora - apoiaram o golpe militar de 1964 que [...] enriqueceu ainda mais as oligarquias do país." Tais “[...] corporaçóes - lideradas pelos múltiplos braços midiáticos das Organizações Globo - anunciaram o golpe como um ataque nobre à corrupçáo de um governo progressista democraticamente eleito. Soa familiar?" Ele segue:

Por um ano, esses ${ }^{2}$ mesmos grupos midiáticos têm vendido uma narrativa atraente: uma população insatisfeita, impulsionada pela fúria contra um governo corrupto, se organiza e demanda a derrubada da primeira presidente mulher do Brasil, Dilma Rousseff, e do Partido dos Trabalhadores (PT). O mundo viu inúmeras imagens de grandes multidóes protestando nas ruas, uma visão sempre inspiradora.

Mas o que muitos fora do Brasil não viram foi que a mídia plutocrática do país gastou meses incitando esses protestos (enquanto pretendia apenas 'cobri-los'). Os manifestantes 
não representavam nem de longe a população do Brasil. Ao contrário, eles eram desproporcionalmente brancos e ricos: as mesmas pessoas que se opuseram ao PT e seus programas de combate à pobreza por duas décadas" (MIRANDA, 2016, s.p).

Miranda ainda salienta que paulatinamente o "[...] resto do mundo começou a ver além da caricatura simples e bidimensional criada pela imprensa local, e a reconhecer quem obterá o poder, uma vez que Rousseff seja derrubada”. A corrupção seria apenas “o pretexto" (MIRANDA, 2016, s.p).

Estes pontos de vista, aliás concordes com os expressados por membros do governo, pela presidenta Dilma e por muitos intelectuais, cientistas e artistas brasileiros, poderiam se diluir no jogo das versóes que se abrem no debate político e frente aos "fatos consumados" em um processo muito complicado de derrubada de um governo eleito e sua substituição por um outro arranjado em antessalas. Porém, o que interessa muito especialmente aqui é que João Roberto Marinho, nada menos que o vice-presidente do Conselho de Administração do Grupo Globo, presidente do Conselho Editorial e do Comitê Institucional do mesmo grupo e vice-presidente da Associação Nacional de Jornais, escreveu uma carta-réplica ao artigo de Miranda e enviou-a ao The Guardian.

Inicialmente, a carta de Marinho, que se assina como "chefe do comitê editorial", foi inserida como resposta ao artigo de Miranda nos "comentários" correntes. A postagem ganhou o título de TV Globo nos solicitou que postássemos a seguinte resposta a este artigo. Nela Marinho salienta que Miranda "[...] pinta um quadro completamente falso do que está acontecendo no Brasil hoje [...]" (MARINHO, 2016, descreve sua versão sobre a chamada "operação lava-jato", a qual tem prendido empresários, políticos e servidores públicos corruptos, especialmente membros do PT e da coalizão de partidos que sustentam o governo e ressalta que "[...] a imprensa brasileira em geral, e particularmente o Grupo Globo, cumprem seu dever de tudo informar, como seria o caso em qualquer outra democracia do mundo". Segue dizendo que o Globo, ao contrário do que descreve Miranda, cobre igualmente os protestos dos "milhóes de brasileiros" em favor da lava-jato, quanto às manifestaçóes em contrário, dos que 
"[...] apoiam o governo [...]", e que sempre os noticia depois de ocorridos, e não antes, portanto, não "[...] incitando protestos de massa". $\mathrm{Na}$ carta-postagem, Marinho ainda declara que "[...] o Grupo Globo náo apoia o impeachment em editorias. Ele simplesmente afirma que, seja qual for o resultado, tudo deve ser conduzido de acordo com a Constituição, o que tem sido o caso até agora”. Para o empresário:

Culpar a imprensa pela atual crise política no Brasil, ou sugerir que ela serve como seu catalizador, é repetir o antigo erro de culpar o mensageiro pela mensagem. Por fim, a afirmação de que o Grupo Globo comanda a mídia nacional, especialmente vindo de um cidadão brasileiro, só pode ser de má fé. A imprensa brasileira é uma vasta e plural paisagem de várias organizaçóes independentes, 784 jornais impressos, 4.626 estaçóes de rádio, 5 redes nacionais de televisão, 216 canais pagos de televisão a cabo e uma grande quantidade de websites. Todos competem zelosamente pela audiência brasileira, a qual, em contrapartida, é livre para escolher. Entre fortes competidores, o resultado final é a independência, sem tolerância a serem conduzidos. Sr. Miranda tem o direito de dizer o que quiser para conseguir os seus objetivos. Ao Grupo Globo resta a responsabilidade de reportar os fatos como eles ocorrem. É nosso dever (MARINHO, 2016, s.p).

Além da discussão e das produçóes acadêmicas a respeito da distribuição dos meios no Brasil e de seu caráter, algo já bastante avançado, que têm mostrado ser totalmente falsa a imagem criada por Marinho em sua missiva sobre a mídia no Brasil, a qual é insistentemente produzida e reproduzida pelos veículos de comunicação que controla e mesmo por seus concorrentes (ver, entre muitos outros, CAPPARELLI; LIMA, 2004; BRITTOS; BOLAÑO, 2005; LATTMAN-WELTMAN, 2003; MARTINS; LUCA, 2008; CHAUI, 2006), interessa atentar para algumas questôes que envolvem a carta de Marinho. Inicialmente publicada como postagem na "vala comum" dos leitores do Guardian - há indicaçôes de que depois o jornal publicou a carta em seção separada -, a manifestação do empresário brasileiro parece ser significativa do turning point pelo 
qual passava a mídia brasileira em sua relação com a mídia internacionalmente dominante, a "mídia do primeiro mundo", durante a crise que se instalou no país.

No jogo das versôes sobre a crise no Brasil, a mídia nativa, como é de se esperar pelo próprio "efeito de campo" na sua relação com o mundo, segundo o qual os jornalistas se referenciam antes de mais nada em seus próprios pares jornalistas (BOURDIEU, 1997), teve sua narrativa reproduzida mundo afora pelas suas congêneres. Laurent Delcourt, em artigo no Le Monde Diplomatique, deixa isso muito claro, ao referir que, em geral, a mídia internacional comprou a versão dominante dos e nos meios dominantes no Brasil de que a crise era devido à corrupção do governo do PT, agora enquadrada judicial e policialmente pela chamada "operação lava-jato". Apenas o Der Spiegel aparecia com "a nota discordante”, segundo a qual o que acontecia era um "golpe frio" engendrado por parte da oposição, do judiciário e pelo "poderoso grupo de televisão" Rede Globo contra o ex-presidente Lula. Delcourt aprofunda a discussão sobre a crise e se afasta da versão simplista até então mais corrente na mídia que é mais ou menos idêntica à que Marinho advoga e explicita na missiva citada (DELCOURT, 2016).

Este parece ser o problema. A própria discussão em termos da nomeação do que ocorre, se "golpe de estado" ou "impeachment constitucional”, revela muito das posiçóes em jogo. É assim que Marinho e a Globo rejeitam a designação "golpe", bem como muitos dos demais agentes envolvidos no processo - políticos, empresariais, latifundiários, associaçóes patronais etc. - e que são claramente contra o governo e a favor da deposição de Rousseff. De outro, entre os que são contra a forma como se está desenrolando o processo, não necessariamente em apoio ao governo, mas contra o que percebem como uma ruptura institucional, a "denúncia de golpe" é um mote importante no sentido de deslegitimar o processo legislativo-judicial de impeachment.

Para resumir, em termos da grande mídia internacional, inicialmente a versão da mídia nativa teve uma aceitação mais imediata. $\mathrm{Na}$ medida em que as contraversóes se foram produzindo, especialmente entre intelectuais e artistas em geral, mas no meio acadêmico em especial, mesmo no meio acadêmico internacional (ver a avaliaçáo de GREEN, 2016), os jornalistas mundo afora começaram a modificar 
suas avaliaçôes e, paulatinamente, a versão da participação visceral da mídia local não como simples mensageira, mas como agente ativo da produção da mensagem e do próprio fato, passa a prosperar. E, nesse caso, a mídia brasileira deixa de ser fonte para se transformar em objeto das reportagens dos meios estrangeiros.

Assim, a carta de Marinho justifica-se tanto no sentido de tentar salvaguardar qualquer nesga de credibilidade jornalística internacional que ainda possa ter o grupo que controla, como também, consequente com o seu papel de agente ativo no golpe em curso, cavar meios de legitimar além e intrafronteiras o golpe e o novo governo que se prenuncia e anuncia. Nesse caso, Marinho está sim muito preocupado com a "imagem" de si no exterior e, inclusive, de acordo com a antiga estratégia de desacreditar o adversário, salienta na carta que Miranda é "cidadão brasileiro", o que o poderia deslegitimar frente aos públicos e meios do "primeiro mundo". Afinal, o cidadão brasileiro Miranda já seria suspeito só por isso, guiar-se-ia, portanto, com base em interesses, pela "má fé", no caso. Já não a Globo, conduzida exclusivamente por seu "dever".

Nesse jogo de criar versóes e representaçóes visando a uma intervenção direta no mundo social (CHAMPAGNE, 2003), algo que está atrelado ao fazer midiático de forma geral, no caso brasileiro se acentua porque, como náo se estrutura um campo propriamente jornalístico ou midiático (GRIJÓ, 2014), as relaçóes entre os grupos empresariais jornalísticos e o mundo empresarial em geral e o mundo político se dão muito mais como uma simbiose do que propriamente como um relação entre distintos. No caso atual, fica muito claro academicamente, mas também midiaticamente quando a representação vem de fora, desde a mídia internacional dominante, que a grande mídia brasileira tomou partido. Mas, como se chegou a isso?

\section{A mídia a reboque}

Antes de mais nada, é importante sublinhar que o regime de 1964, na medida em que foi se instalando depois do golpe de 31 de março, e, em especial, com a legislação e os Atos Institucionais, passou a controlar os meios de comunicação quanto às concessóes de canais 
e aos conteúdos que podiam ou não ser veiculados. Também forçou a dissolução de empresas de comunicaçáo identificadas com o antigo PTB ou que fizessem oposição explícita a ele, sendo a maior vítima o grupo empresarial de Samuel Weiner, Última Hora. Por atos de força, como exílios de jornalistas e opositores em geral, por estrangulamento econômico, ou pela adesão prévia e mesmo auxílio direto na derrubada do presidente João Goulart, o regime foi garantindo uma imprensa bastante dócil no que se refere a críticas e divulgação de informações. Por outro lado, foi incentivando a estruturação de grandes conglomerados nacionais de teledifusão. Entre 1964 e 1980, quando tecnicamente o veículo televisão transforma-se e se massifica, as empresas receberam o apoio fundamental do Estado, especialmente com subsídios diretos e indiretos e, com a Embratel e a conexão nacional no sistema interligado de comunicaçôes, permitiu a formação das redes nacionais de televisão seguindo o modelo norte-americano. Desde então, o seu crescimento é constante e acentuado. A partir do salto das décadas de 1960-1970, quando passou-se de 598.000 aparelhos de televisão no início do período para algo em torno de 4.584 .000 ao seu final, em 1980, já haviam 18.300.000 deles, como o gráfico 1 demonstra.

\section{Gráfico 1 - Número de aparelhos de televisão em uso no país por ano}

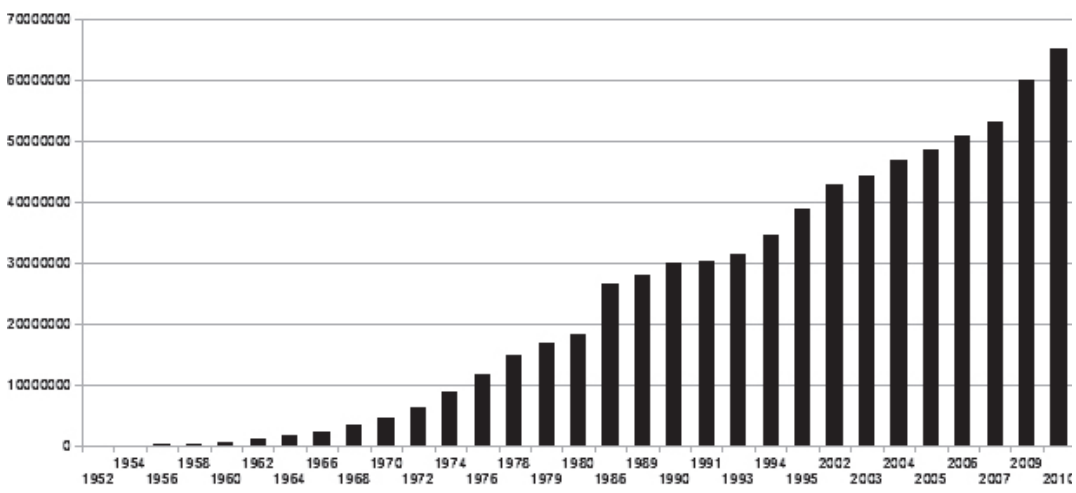

Fonte: Elaborado com os dados de MATOS, Sérgio. História de televisão brasileira. Petrópolis: Vozes, 2010, p. 91. 
Já segundo o senso de 2010 do IBGE, 95,1\% das residências possuíam aparelhos de televisão e $81,4 \%$ aparelhos de rádio. Pela primeira vez na história, os aparelhos de televisão suplantavam os de rádio nas residências do país (ver IG São Paulo, 2015). Por outro lado, se esses dados são cruzados com os da população do país, tem-se que em 1960 havia 0,000004 aparelhos de televisão por habitante, enquanto que em 1980 eram 0,15 aparelhos por habitante, não por domicílio, o que, se considerado, torna o número de pessoas com acesso aos aparelhos muito maior.

A televisão foi-se constituindo no veículo de massas por excelência e os governantes náo ficaram alheios a isso. A já bastante comprovada aliança entre os empresários privados e o governo nesse modelo de organização (GOULART; RIBEIRO; ROXO, 2010, p. 117-118; CAPARELLI, 1982; CAPARELLI; LIMA, 2004 e outros) levou à formaçáo do atual oligopólio privado que caracteriza o setor. Se estruturaram as grandes empresas de comunicação que se estabeleceram em nichos de mercado em um ambiente de pseudocompetição, pois as organizaçôes Globo assumiram um papel quase monopolístico nessa área, não só atuando como padrão ou modelo para todo o setor, mas atingindo índices absurdamente altos de audiência relativos em algumas de suas programaçôes-ônibus, para usar uma expressão de Pierre Bourdieu (1997, p. 23).

Está também muito demonstrado e assentado na bibliografia (SODRÉ, 1977; BARBOSA, 2007; MOREL, 2008) a dependência que os meios sempre tiveram dos grupos políticos no Brasil. Pode-se, inclusive, afirmar que a imprensa surgiu no país atrelada aos posicionamentos políticos de seus controladores, fossem estes cidadãos privados, como Caldas Júnior e seus sucessores, fossem estes organizaçóes, como o caso de $A$ Federação, órgáo do Partido Republicano Rio-Grandense (PRR), para ficar no exemplo do Rio Grande do Sul (RÜDIGER, 2003). Por outra, a imprensa era uma espécie de apêndice ou um recurso a mais nas mãos de agentes políticos. Com efeito, ela surgiu a reboque das disputas político-partidárias e assim permaneceu até muito recentemente.

Os casos são inúmeros, mas é emblemática a configuração destes veículos nos momentos que antecederam o golpe de 1964. O Globo (Roberto Marinho) e O Estado de São Paulo (Júlio de Mesquita Filho), 
sem falar na Tribuna da Imprensa (Carlos Lacerda), perfilaram-se em favor do golpe, enquanto que o Última Hora, então um conjunto de jornais espalhados pelo país, de Samuel Weiner, perfilava-se em favor do governo trabalhista de João Goulart. Caso emblemático à época é o do jornal Luta Democrática, de propriedade de Tenório Cavalcanti, o "Homem da Capa Preta". De acordo com os posicionamentos partidários de seu dono, o jornal do político udenista nasceu como um instrumento ferrenho de oposição a Getúlio Vargas e ao seu genro Ernâni do Amaral Peixoto, líder político fluminense. Mas isso até que Tenório passou a se aproximar de João Goulart, já depois da morte de Vargas, e se afastar da UDN, posição na qual se encontrava quando do golpe de 1964. Daí em diante, o jornal seguiu o caminho de seu proprietário, cassado e obscurecido pelo novo regime, entrando em decadência até ser negociado nos anos 1970 (GRYNSZPAN, 1990).

Até a ditadura de 1964, inclusive, a imprensa esteve a serviço ou muito próxima dos líderes e grupos políticos que se enfrentavam nas disputas partidárias. Mas isso não é totalmente exato. Se é possível constatar tal relaçáo com as disputas políticas, essa é apenas uma das facetas da questão, pois, sem necessariamente a ela se contrapor, a imprensa era também um negócio, negócio privado vinculado a empreendedores que visavam ao lucro (LUCA, 2008, p. 153-154). Estas duas dimensôes conviviam relativamente bem: imprensa-empresa e imprensa-partidária. Com a ditadura, houve a depuração dos reais ou virtuais opositores, sendo que os que sobraram foram brindados com a possibilidade de seu faturamento crescer juntamente com o seu fortalecimento como empresas capitalistas que produziam bens para o consumo de massa. Isso foi possível pela própria expansão do mercado em geral, seja para os produtos da imprensa escrita, que se beneficiaram dos programas de alfabetização e difusão do ensino, seja para os produtos dos meios eletrônicos, especialmente pela passagem da "era do rádio" para a "era da televisão". O chamado "milagre econômico", que durou até aproximadamente 1973, diversificou a economia do país e consolidou um mercado nacionalizado, integrado e em expansão, do que a imprensa-empresa beneficiou-se diretamente. Mas isso, evidentemente, às custas da despolitização desses meios, despolitização no sentido de se verem impedidos de participar livremente da luta 
político-partidária. Então, a questão não era "falar bem" ou "falar mal" do governo, ou seja, de aderir à situação ou à oposição, mas de divulgar docilmente o que se podia e silenciar quanto ao resto. Assim operava a censura, deixava os meios e seus profissionais serem jornalísticos ou artísticos até o ponto em que era possível, até o ponto em que os produtos pudessem passar a ser percebidos como ameaçadores à ordem estabelecida. Dessa forma, a censura ou os outros meios de coação passavam a operar, entre os quais a autocensura exercida pelos próprios profissionais sobre eles mesmos ou por seus superiores hierárquicos até chegar nos donos das empresas.

Uma questão que se abre é a de como e por que essas empresas que cresceram e se fortaleceram à sombra de um regime a elas tão benéfico optariam por, na medida em que ele entrava em crise, posicionar-se, mesmo que como empresas de comunicação, sem tomar o seu partido, o partido do regime?

É possivel de se pensar que o regime ditatorial, ao despolitizar forçosamente, em termos da livre atuação político-partidária, os meios e os seus profissionais, esses últimos provavelmente os mais incomodados com isso, acabou canalizando os recursos e o foco das empresas para o seu lado propriamente empresarial, para a lucratividade econômica relativa, cada qual com suas possibilidades mais ou menos garantidas por lei pelas concessóes de rádio e televisão, pelos nichos que passaram a ocupar, pela expansáo do mercado de livros didáticos e paradidáticos e de impressos dos mais diferentes tipos, ou pelas conexôes e outros tipos de relaçóes que estabeleciam como empresas, como no caso dos direitos de reprodução de gibis e outros tipos de publicaçóes estrangeiras no Brasil. Em outras palavras, a despolitizaçâo relativa dos meios como sua docilidade e subserviência, veio ao encontro de seu fortalecimento empresarial, cujas condiçôes para tal eram possibilitadas, garantidas e mantidas pelas políticas públicas do governo. Note-se, no entanto, que cumpriam um importante papel político-partidário, o de brindar suas audiências com produtos inócuos sob o ponto de vista da crítica social e política. Quer dizer, paradoxalmente, foram politizados em outro sentido, no sentido de instrumentos da manutenção do status quo, tomaram o partido do governo. 
É este ambiente favorável e acolhedor que passa a sofrer transformaçóes com a crise do regime. Ainda rebocados pela política partidária, os meio viram-se envolvidos no retorno significativo dos cidadáos às ruas com as greves do final dos anos 1970 e com as manifestaçôes em favor da anistia e da redemocratizaçáo, principalmente nos anos 1980.

É emblemática a posição daquela organização que mais ganhou com o regime à sombra do qual estruturou uma extensa rede de televisão e um diversificado grupo empresarial de comunicação espalhado por todo o país, que, além de ampliar suas propriedades horizontal, vertical e cruzada de muitos e diversos meios de produção e difusão de bens culturais, acumulou lucros significativos. O grupo Globo chegou a ignorar a campanha "Diretas Já", quando, em 1983-1984, uma série de manifestaçóes pelo país lideradas por segmentos organizados da sociedade - partidos, sindicatos, associaçóes profissionais etc. - colocou milhóes de pessoas nas ruas das principais cidades reivindicando a volta das eleiçôes livres e diretas para presidente da Republica. Inclusive, noticiou que o evento realizado na Praça da Sé em Sáo Paulo era relativo ao aniversário da cidade, e não ao ato político (FANTINATTI, 2007).

Não é objetivo aqui enumerar as açóes e omissóes nesse sentido que as empresas de comunicação realizaram ao longo da chamada abertura política dos anos 1980. É importante notar que ainda aqui os meios foram a reboque dos acontecimentos. A sociedade organizada em sindicatos, partidos, associaçóes profissionais se pôs à frente dos acontecimentos que levaram ao final do regime de exceção em um processo de transição, negociação e transação que foi habituando e reposicionando os grupos sociais e políticos de acordo com as novas condiçóes estabelecidas, das quais a Constituição de 1988 é o resultado institucional.

A sociedade em geral e os grandes grupos de comunicaçáo em particular tiveram que se adaptar às novas condiçôes de se fazer política no Brasil. O que parece é que a relutância inicial dos meios, alguns dos quais nem ao menos registravam jornalisticamente o que ocorria de contestação ao regime moribundo, é um indicador dessa dívida para com ele e da segurança que sob ele possuíam, muito bem aninhados e abrigados. Porém, findos os momentos iniciais de 
desconfianças e incertezas, as empresas passaram a atuar fortemente nas novas condiçóes que, ao fim e ao cabo, acabaram por se mostrar até mesmo mais favoráveis a elas do que eram no regime anterior. Por isso acabaram elas também abandonando o barco do regime militar junto com os demais náufragos que nadavam em direção às oposiçôes em número cada vez maior na medida em que mais fraco ele se tornava. No processo procuravam se adaptar, se reposicionar, e em seu socorro havia já uma quantidade razoável de "expertos" que, tendo estudado fora do Brasil, especialmente nos Estados Unidos, ou sofrendo a influência do que lá se produzia, influência percebida nas muitas e multiplicadas escolas de comunicação, administração, propaganda e marketing criadas no Brasil, podiam fornecer os instrumentos de adaptaçáo dos meios ao regime democrático que se criava. Marqueteiros, publicitários, administradores e mesmo jornalistas, é interessante aqui citar a conversão de Paulo Francis, que migrou sem escalas de um trotskismo difuso para o neoliberalismo (BATISTA, 2015), estavam disponíveis e se dispuseram a cooperar ou operar por eles mesmos ou por sua expertise técnica e influência simbólica os reposicionamentos destes e dos outros tantos grupos empresarias do país, muitos dos quais contribuíram com o regime que findava com algo bem mais do que apoio moral.

Os meios de comunicação acabaram por se tornar, na avaliação de Lattman-Weltman:

[...] a instituição mais decisiva para a qualidade da cidadania no Brasil redemocratizado. Ela impóe suas coordenadas e linguagens específicas sobre as estratégias para as principais disputas eleitorais; fornece os principais elementos simbólicos e cognitivos para a escolha do eleitor; forja - conscientemente ou não - consensos sobre a pauta política e institucional; define, de um modo ou de outro, a agenda política, dos seus termos mais graves a alguns dos mais específicos (LATTMAN-WELTMAN, 2003, p. 129-30).

Estas noçôes, provenientes da "teoria da agenda" de Mc Combs (2009), relacionam-se à questáo de avaliar qual seria a capacidade dos 
meios de proporem o que é pensável e discutível como problemáticas públicas e, portanto, políticas no mundo das democracias modernas.

Antes de mais nada, no entanto, há que se ter cuidado em não exagerar demasiadamente o papel dos meios nesse sentido, quer dizer, é preciso se armar contra a possibilidade de cair na esparrela da "mídia como quarto poder", discurso dos próprios agentes do meio sobre eles mesmos e suas ocupaçóes e muito caro a eles, pois assim se elevam a uma posição paraconstitucional e institucional bastante conveniente, reduplicam sua importância e constroem para si mesmos e seu papel no mundo um lugar de destaque. Isso não é só um trunfo no jogo político mais amplo, mas também na racionalização e no recrutamento dos "jovens jornalistas" que, ao ingressarem nas redaçóes e nos estúdios dos grandes meios, embora mal remunerados financeiramente e suportando jornadas de trabalho estafantes, são investidos e se autoinvestem de um poder extraordinário como agentes de um poder paralelo. Ou seja, recebem em retribuição uma espécie de compensação simbólica e o vislumbre dos melhores dias quando chegarem, o que é para muito poucos, na posição dos bemsucedidos, tornarem-se winners.

Voltando à questão do poder de agenda, é sem dúvida a partir da crença nessa possibilidade que os meios influenciam e atuam diretamente sobre o pessoal político, o qual, por sua vez, costuma mendigar espaços nos meios para aparecer comme il fault, na suposição de reforçar sua imagem junto aos seus apoiadores e frente a seus concorrentes internos. Tirando as centenas de importantíssimas microrrelaçóes e interesses compartilhados entre políticos e jornalistas e entre empresários dos meios e políticos, muitos deles, agentes e interesses, venais e figadais, pois aqui não haveria espaço para analisá-los convenientemente, enquanto um conjunto de instituiçóes agindo na e sobre a sociedade, os meios, sem dúvida, como bem demonstrou Patrick Champagne (1998), vão torcendo em benefício dos recursos que melhor dominam e, portanto, de si mesmos, as regras e pautas do jogo político, procurando transformar, entre outras coisas, aquilo que se convencionou chamar de opinião pública em uma instância mensurável, controlável, identificável e manipulável, enfim, domesticada (BOURDIEU, 1987). Os mecanismos de medição de gostos e interesses que são aplicados aos índices de 
audiência são aplicados do mesmo modo à opinião pública, que passa a se constituir na instância máxima de legitimação dos meios como tais, uma vez que ninguém votou em apresentadores de televisão, como Gugu e Faustão, ou em âncoras de telejornais, como William Waack e Boris Casoy, para que ocupassem os lugares que ocupam, ao mesmo tempo em que passa a ser aquela a instância em nome da qual os meios se autoarrogam o "dever" de em seu nome falar e da qual se apresentam como intérpretes e protetores dos seus interesses e gostos pré-fabricados.

\section{A mídia rebocada}

Paulatinamente os meios foram se aclimatando à democracia e se fortalecendo em sua influência sobre a política até a situação atual em que não mais são rebocados por ela, mas tentam constantemente inverter a equação em seu favor, tornando-a sua refém. É nesse sentido que a democracia foi sequestrada, de uma conquista da sociedade passou a ser identificada pelos meios como tendo sido produto de uma luta por eles capitaneada. Novamente é interessante o caso analisado por Fantinatti a respeito da campanha das Diretas Já e a Rede Globo. Tentando reverter a representação mais do que corrente, não só pelo que se escreveu como bibliografia, mas também pela memória daqueles que vivenciaram o período, de que a empresa procurou ignorar o quanto pode aqueles atos e, principalmente, o seu o conteúdo político, tentando inclusive manipulá-los em favor de representaçôes fantasiosas, atualmente tem tentado reverter essa imagem, denegando que seja correta esta versáo mais corrente e assentada. Assim, publicaçóes recentes da emissora sobre sua "memória" passam a "apostar":

[...] na afirmação de que aquele que seria considerado o principal comício pelas 'Diretas Já' não foi omitido do público; que uma crítica comumente dirigida à Globo não passaria de uma falsa versão, baseada em mitos. [...] Segundo [... suas] publicaçóes, no que se refere ao movimento pelas Diretas: a) a Globo cobriu os comícios e noticiou o mais importante, o da 
Praça da Sé, em seu Jornal Nacional; b) a verdadeira motivação para as críticas dirigidas à Globo estaria no fato de haver uma expectativa, entre os proponentes do movimento, de que a emissora apoiasse as Diretas; c) quem critica a Globo perde de vista o momento político e o feroz papel da censura, ao qual ela estava mais ostensivamente exposta, principalmente pelo destaque que tinha, em termos de audiência, em relação a qualquer outro meio de comunicaçáo. Por último, merece atenção um ponto especialmente polêmico, sobre o qual, parece não haver unanimidade: Kamel (2003) opina que a Globo praticou bom jornalismo (FANTINATTI, 2007, p. 2-3).

Tenta-se transformar o jornalismo nenhum em "bom jornalismo" na perspectiva de criar versóes que, ao fim, mesmo sendo elas rechaçadas no momento, entram no mundo relativo das versóes as quais, ao confundir, absolvem. Enfim, no fundo e segundo ela mesma, a Globo sempre foi em favor da "luta democrática”. Em uma das grandes passagens da literatura, Tomasi di Lampedusa, em $O$ Gattopardo, descreve a cena na qual o príncipe de Salinas é convidado por um emissário do novo governo da Itália recém-unificada a compor o Senado do Reino em Turim. Recusando o convite, Don Fabrizio diz: "[...] como o senhor não terá podido deixar de reparar, não tenho ilusóes; que utilidade teria eu para o Senado, um legislador inexperto a quem falta a capacidade de enganar a si próprio, esse requisito essencial para quem quer guiar os outros?" (LAMPEDUSA, 2007, p. 220). Empilhando versôes semifalsas e semiverdadeiras, tentando fazer crer para dentro e para fora que o que se constrói como fato o é de fato, vai-se ao encontro da objetivação da versão que finda por se tornar parte da verdade factual (BOURDIEU, 1981). O engano e o autoengano sustentam a pretenção à dominação.

Por isso Marinho empenhou-se em responder a um ativista que escreveu um artigo em um meio de comunicação de primeira grandeza, The Guardian, na constelação midiática internacional. Desacredite-se o autor, um "interesseiro de má fé” em nome da imaginativa afirmação de credibilidade e cumprimento do dever de uma instituição como a Rede Globo. 
Do mesmo modo, os meios tentam fazer crer na estreitíssima identificação entre democracia, liberdade de expressão e liberdade de imprensa. Investidos em defensores dessas liberdades, colocam-se na posição de curadores da democracia, sinônimo de liberdade. Em um discurso proferido na ocasião do lançamento da Rede em Defesa da Liberdade de Imprensa, o então presidente da Associação Nacional de Jornais (ANJ), mas também dono do conglomerado empresarial e de comunicação Rede Brasil Sul (RBS), um dos mais ricos do país, Nelson Sirotsky, disse o seguinte:

A defesa intransigente da liberdade de imprensa é um compromisso histórico e fundamental da Associação Nacional de Jornais, assumido desde sua fundação. [...] Para nós, que temos o honroso papel de informar diariamente o País, a liberdade é um elemento vital, sem o qual fica definitivamente comprometido o sentido da nossa atividade. Sem a liberdade de informação e opiniáo, fica comprometida a democracia e todas as instituiçôes dela derivadas. [...] Desde 1997 a ANJ mantém seu Programa de Defesa da Liberdade de Imprensa, com o objetivo de desenvolver açôes para garantir a liberdade de informação e opinião no Brasil e denunciar qualquer tipo de ameaça ao livre exercício da nossa atividade. [...] Na nossa visão, o conceito de liberdade está inteiramente relacionado à ética (SIROTSKY, 2005, s.p.).

Já o Código de Ética da ANJ explicita em um de seus artigos que os jornais brasileiros têm o "compromisso incondicional" de "[...] sustentar a liberdade de expressão, o funcionamento sem restriçóes da imprensa e o livre exercício da profissão" (SIROTSKY, 2005, s.p.).

A manifestação oficial do presidente da associação dos jornais brasileiros, ou melhor, de seus proprietários, posição que ocupa João Marinho no momento (2016), deixa claro que, para eles, zelar pela liberdade de expressão é uma missão que se confunde com a liberdade de imprensa a qual, por sua vez, confunde-se com a democracia, pois é um dos seus sustentáculos. Tudo isso dentro de um conjunto de condutas definidas para eles por eles próprios em seu Código de Ética. Até então, tudo parece muito nobre, elevado e sublime. Mas, 
há um outro ponto no tal Código: a ANJ deve "[...] defender os direitos do ser humano, os valores da democracia representativa e a livre iniciativa" (SIROTSKY, 2005). Agora o rol das "liberdades" essenciais na democracia e para a democracia sob essa leitura patronal se completa: liberdade de expressão=liberdade de imprensa=liberdade de empresa. Isso é "liberdade" para os donos dos jornais no Brasil. E, por isso, no mesmo documento, uma advertência ao governo federal que pretendia criar um "[...] Conselho Federal de Jornalismo, uma iniciativa equivocada [...] que o Congresso, muito oportunamente, teve a sabedoria de arquivar" (SIROTSKY, 2005, s.p.).

Tornar a democracia e a liberdade de expressão como reféns de seus pontos de vista é expressamente um posicionamento político. Tutelando as instituiçóes os meios espraiam e impóem uma visão ou uma versão do que devam ser a democracia e as liberdades concordes com a visão e a versão que eles próprios têm da questão. Os meios buscam se apresentar à sociedade como os novos guardióes da ordem e das instituiçóes públicas, os árbitros do que pode ou não pode ser politicamente pensado ou discutido, destronando ou suplantando outros grupos sociais que assim agiram no passado no país, como os militares e a Igreja Católica. Pode-se inclusive a tal respeito pensar que se os militares que se retiraram da participaçáo política mais ostensiva e direta, ao acolherem e nutrirem os atuais grupos de comunicação quando dominavam politicamente, deixaram no controle da situação atual os seus afilhados. $\mathrm{O}$ discurso de Sirotsky sintomaticamente termina com: "[...] o futuro nos pertence e depende da nossa vigilância e do nosso empenho em construí-lo num ambiente verdadeiramente democrático. É para isto que veio a Rede em Defesa da Liberdade de Imprensa" (SIROTSKY, 2005). É também por isso que é importante na situação atual vetar a representação "golpe de estado". Segundo Marinho, como já citado, o que ocorre está dentro da lei, da "Constituição". Os grandes grupos midiáticos nacionais podem continuar a exercer sua tutela e vigilância sobre a democracia que estaria assim resguardada.

Nesse sentido é que os meios podem ser tomados como partido político, náo somente no sentido de um suposto Partido da Imprensa Golpista (PIG) que a luta política atual lhes têm aposto, mas no sentido de Gramsci, de partido político como instância da sociedade 
civil organizadora da hegemonia e da dominação (GRAMSCI, 1980, p. 29-30). Operando essa tutela sobre o regime democrático e buscando torcê-lo e defini-lo em seu benefício, os meios centralizam e organizam a produção cultural de sentido de modo a legitimar a dominação que eles exercem juntamente com os demais agentes socialmente dominantes. É por isso que, ao fim e ao cabo, acabam por se chocar com outras instâncias de proposição de problemas políticos, de alternativas à agenda estabelecida, como muitos movimentos sociais, alguns políticos mais autônomos frente aos meios, e mesmo uma ou outra facção de algum partido político instituído.

É, porém, importante sublinhar que isso se trata do movimento que os meios fazem em seu benefício, o que não significa que não encontrem contestação ou resistência. É assim que, quando no dia quinze de março de 2015, a manifestação que contou com a decisiva participaçáo deles em sua arquitetura e convocação nas páginas dos seus jornais, telas de televisão e aparelhos de rádio, o que foi depois por eles insistentemente apresentado como "movimento espontâneo organizado pelas redes sociais", caracterizou-se como uma espécie de espelho dos grupos socialmente dominantes. Tirando as faixas e os cartazes de grupos organizados mais radicais que pregavam a subversão das instituiçôes ou se apresentavam com slogans sexistas, de caláo, preconceituosos etc., na maioria das vezes beirando o, senão cometendo, crime, os meios esforçaram-se em mostrar atos carnavalizados, coloridos, bem-humorados, sem violência, quase ascéticos, impolutos. Transformam a política em espetáculo de boulevard, tanto no sentido de que levado às ruas, quanto no sentido de elitista, "para as famílias", com o claro objetivo de tornar o governo cada vez mais refém da sua agenda e, mais recentemente, tentando derrubá-lo de vez.

Ao contrário dos protestos de junho de 2013, violentos, arredios e hostis à própria imprensa, críticos, radicais e extremistas que tiveram como mote inicial a alta no preço das passagens de ônibus, a manifestação do dia quinze de março de 2015 teria sido pacífica e da "gente de bem" contra a "corrupçáo" e, eventualmente, contra o "governo do PT", identificado como promotor da suposta corrupção. Ou seja, os meios têm comparecido diretamente na arena política como força organizadora e canalizadora de diversos interesses na sociedade, muitos deles absolutamente legítimos, mas 
outros nem tanto. Aquele quinze de março foi um dia que marcou simbolicamente essa modificaçáo relativa na posiçáo dos meios no Brasil que está aqui em pauta. Até a campanha das Diretas Já e mesmo no processo de impeachment de Fernando Collor de Melo, os meios foram atrás dos movimentos que se originaram em outros lugares, nos partidos, nas associaçôes, nos sindicatos, entre líderes políticos e forças empresariais, embora o último possa ser visto como um caso de transição. Em quinze de março foram os meios que claramente rebocaram e canalizaram descontentamentos nessa forma de manifestação de boulevard que tomou os contornos de um verdadeiro happening e, desde então, têm capitaneado o processo de impeachment da atual presidenta buscando fazer crer se tratar de algo "normal", totalmente de acordo com as "instituiçôes democráticas" das quais se arrogam a tutela.

\section{Consideraçóes finais}

As consequências que isso tem para a democracia em geral e, mais especificamente, para a democratização dos bens e meios de produção materiais e simbólicos na sociedade são graves. Pierre Bourdieu salienta, a respeito da televisão, que ela "[...] expóe a um grande perigo as diferentes esferas da produçáo cultural, arte, literatura, filosofia, direito [...]", bem como a "um perigo não menor a vida política e a democracia” (BOURDIEU, 1997, p. 9-10). Chauí também aponta que os meios de comunicação, ao creditarem uns especialistas em produção de sentido, ao mesmo tempo em que descreditam outros, "[...] aparecem com a capacidade mágica de fazer acontecer o mundo." Esta seria uma "[...] competência suprema, a forma máxima de poder: o de criar a realidade" (CHAUÍ, 2006, p. 78). Em parte isso viabiliza a presunção de João Marinho de que o que tem ele a dizer é mais significativo e pesado do que tem a dizer um cidadão qualquer "de má fé". É ele quem tem o poder de dizer o que é, não um outro supostamente desqualificado para tal.

Como se pode vivenciar no momento, um dos riscos é que, se os intentos tutelares explícitos dos grandes grupos empresariais do setor de fato mantiverem-se sem a contestação que por ora ainda 
sofrem, ou com ela diminuída e enfraquecida por sua criminalização e perseguição pelos próprios meios e pelas instituiçóes jurídico-policiais fortemente influenciadas por eles, a democracia e a liberdade paradoxalmente podem se ver castradas, vetadas e derrotadas pela própria democracia e pela liberdade da imprensa-empresa dominante.

\section{KIDNAPPED DEMOCRACY: MEDIA AND POWER IN TODAY'S BRAZIL}

Abstract: This article aims to analyze how media behaved in Brazil since the civil-military dictatorship until today. Linked to large companies in the sector, which is now better known as the mainstream media, the media have come to play in the social world as a whole, especially in relation to the new conditions of doing politics that opened with the so called process of democratic opening, a central position in society and especially in political disputes. From towed by politics, now tows it, posting up as guardians and interpreters of democracy, lending it the way that best suits them.

Keywords: Media. Coup and media. Democracy and media.

\section{Notas}

${ }^{1}$ Todas as referências deste parágrafo são citações orais, pertencentes a uma matéria da CNN (2016).

${ }^{2}$ Todas as referências deste parágrafo pertencentes a Miranda, (2016, s.p).

\section{Referências}

ABREU, Alzira Alves de; LATTMAN-WELTMAN, Fernando; KORNIS, Mônica Almeida (Org.). Mídia e política no Brasil: jornalismo e ficção. Rio de Janeiro: FGV, 2003.

FGV, 2003.

. (Orgs.). Mídia e politica no Brasil: jornalismo e ficção. Rio de Janeiro:

BARBOSA, Marialva. História cultural da imprensa: Brasil, 1900-2000. Rio de Janeiro: Mauad X, 2007.

. História da comunicação no Brasil. Petrópolis: Vozes, 2013.

Anos 90, Porto Alegre, v. 23, n. 43, p. 67-92, jul. 2016 
BATISTA, Alexandre Blankl. A trajetória de Paulo Francis na imprensa hegemônica e contra-hegemônica brasileira (1962-1997). Tese (Doutorado em História), PPG em História/UFRGS, 2015.

BOURDIEU, Pierre. A opinião pública não existe. In: THIOLLENT, Michel J. M. Crítica metodológica, investigação social \& enquete operária. São Paulo: Polis, 1987. p. 137-151.

Descrever e prescrever: nota sobre as condiçóes de possibilidade e os limites da eficácia política. Tradução para fins didáticos de Décrire et prescrire: note sur les conditions de possibilité et les limites de l'eficacité politique. Actes de la recherche en sciences sociales, p. 69-73, maio, 1981.

. Sobre a televisão. Rio de Janeiro: Jorge Zahar, 1997.

BRITTOS, Valério Cruz; BOLAÑO, César R. Siqueira (Orgs.). Rede Globo: 40 anos de poder. São Paulo: Paulus, 2005.

CAPPARELLI, Sérgio; LIMA, Venício A. de. Comunicação e televisão: desafios da pós-globalização. São Paulo: Hacker, 2004.

- Comunicação e televisão: desafios da pós-globalização. São Paulo: Hacker, 2004.

CAPPARELLI, Sérgio. Televisão e capitalismo no Brasil. Porto Alegre: L\&PM, 1982.

CHAMPAGNE, Patrick. A visão mediática. In: BOURDIEU, Pierre (Org.). A miséria do mundo. Petrópolis: Vozes, 2003, p. 63-79.

. Formar a opinião: o novo jogo político. Petrópolis: Vozes, 1998.

CHAUÍ, Marilena. Simulacro e poder - uma análise da mídia. São Paulo: Fundação Perseu Abramo, 2006.

. Simulacro e poder - uma análise da mídia. São Paulo, Fundação Perseu Abramo, 2006.

CNN. Christiane Amanpour - reportagem sobre votação da permissão de abertura do processo de impeachment de Dilma Rousseff pela Câmara. In: http://edition. cnn.com/videos/tv/2016/04/18/intv-amanpour-glenn-greenwald-dilma-rousseff-impeachment.cnn. Acesso em: 3 maio 2016.

CRUZ, Dulce Márcia. Televisão e negócio: a RBS em Santa Catarina. Florianópolis/Blumenau: UFSC/FURB, 1996.

DELCOURT, Laurent. Brazil's cold coup. In. Le monde diplomatique - english edition. Disponível em: https://mondediplo.com/2016/05//02brazil. Acesso em: 02 maio 2016. 
FANTINATTI, Márcia. A cobertura jornalística da campanha pelas "Diretas já": o fantasma que ainda assombra a história da Rede Globo. In: Intercom - Sociedade Brasileira de Estudos Interdisciplinares da Comunicação - V Congresso Nacional de História da Mídia, São Paulo, 31 de maio a 02 de junho de 2007. Disponível em: http://www.ufrgs.br/alcar/encontros-nacionais-1/encontros-nacionais/5o-encontro-2007-1/A\%20 cobertura $\% 20$ jornalistica $\% 20 \mathrm{da} \% 20$ campanha $\% 20$ pelas\%20201cDiretas\%20ja201d.pdf. Acesso em: 22 mar. 2015.

GOULART, Ana Paula; RIBEIRO, Igor Sacramento; ROXO, Marco (Orgs.). História da televisão no Brasil. São Paulo: Contexto, 2010.

GRAMSCI, Antonio. Notas sobre Maquiavelo, sobre la politica y el Estado moderno. Madri: Nueva Visión, 1980.

GREEN, James Naylor. As instituiçóes democráticas não estão funcionando. In: Carta Capital. Disponível em: http://www.cartacapital.com.br/revista/899/ volta-ao-passado?utm...3\&utm_medium=social\&utm_source=twitter.com\&utm_ campaign=buffer, entrevista a Eduardo Graça. Acesso em: 5 maio 2016.

GRIJÓ, Luiz Alberto. A mídia brasileira no século XXI: desafios da pesquisa histórica. In: FERREIRA, Marieta de Moraes; DELGADO, Lucilia de Almeida Neves. (Org.). História do tempo presente. Rio de Janeiro: Editora FGV, 2014. p. 279-298. GRYNSZPAN, Mário. Os idiomas da patronagem: um estudo da trajetória de Tenório Cavalcanti. Revista brasileira de ciências sociais, n. 14, p. 73-90, out., 1990. HABERMAS, Jürgen. Mudança estrutural da esfera pública. Rio de Janeiro: Tempo Universitário, 2003.

IG São Paulo. IBGE: pela $1^{\text {a }}$ vez, domicílios brasileiros têm mais TV e geladeira do que rádio. Disponível em: http://ultimosegundo.ig.com.br/brasil/2012-04-27/ ibge-pela-1-vez-domicilios-brasileiros-tem-mais-tv-e-geladeira-d.html. Acesso em: 23 mar. 2015.

LAMPEDUSA, Tomasi di. O Gattopardo. Rio de Janeiro: BestBolso, 2007.

LATTMAN-WELTMAN, Fernando. Mídia e transição democrática: a (des) institucionalização do pan-óptico no Brasil. In: ABREU, Alzira Alves de; LATTMAN-WELTMAN, Fernando; KORNIS, Mônica Almeida (Org.). Mídia e política no Brasil: jornalismo e ficção. Rio de Janeiro: FGV, 2003. p. 129-183.

LUCA, Tânia Regina de. A grande imprensa na primeira metade do século XX. In: MARTINS, Ana Luiza; LUCA, Tânia Regina de (Org.). História da imprensa no Brasil. São Paulo: Contexto, 2008. p. 149-175.

LUHMANN, Niklas. A realidade dos meios de comunicação. São Paulo: Paulus, 2005. 
MAC COMBS, Maxwell. A teoria da agenda - a mídia e a opinião pública. Rio de Janeiro: Vozes, 2009.

MARINHO, João Roberto. Resposta ao artigo de David Miranda. In: Jornal GGN. Disponível em: http://jornalggn.com.br/noticia/a-carta-de-joao-roberto-marinho-ao-the-guardian. Acesso em: 23 abr. 2016.

MARTINS, Ana Luiza; LUCA, Tânia Regina de (Org.). História da imprensa no Brasil. São Paulo: Contexto, 2008.

MATOS, Sérgio. História da televisão brasileira - uma visão econômica, social e política. Petrópolis: Vozes, 2010.

MELO, José Marques de. História social da imprensa. Porto Alegre: Edipucrs, 2003.

MIRANDA, David. A razão real por que os inimigos de Dilma Rousseff querem seu impeachment. In: The Guardian. Disponível em: http://www.the guardian.com/commentisfree/2016/apr/22/razao-real...os-de-dilma-rousseff-querem-seu-impeachment?CMP=share_btn_link, em inglês, http:// www.theguardian.com/commentisfree/2016/apr/21/dilma-rousseff-enemies-impeached-brazil. Acesso em: 24 abr. 2016.

MOREL, Marco. Os primeiros passos da palavra impressa. In: MARTINS, Ana Luiza; LUCA, Tânia Regina de (Orgs.). História da imprensa no Brasil. São Paulo: Contexto, 2008.

RÁDIO GAÚCHA. Programa Gaúcha Repórter, 02 de maio de 2016.

RÜDIGER, Francisco. Tendências do jornalismo. Porto Alegre: Editora da UFRGS, 2003.

SIROTSKY, Nelson. A defesa da liberdade de imprensa no Brasil. Brasília, UNESCO, 2005. Disponível em: http://www.livrosgratis.com.br/arquivos_livros/ ue000266.pdf. Acesso em: 21 fev. 2014.

SODRÉ, Nelson Werneck. História da imprensa no Brasil. Rio de Janeiro: Graal, 1977.

THE INTERCEPT. Perfil de Glenn Greenwald. Disponível em: https://theintercept.com/staff/glenn-greenwald. Acesso em: 3 maio 2016.

Recebido em: 10 / $12 / 2015$

Aprovado em: 20 / 03 / 2016 